\title{
POLITICALLY CONNECTED FIRMS AND THEIR STOCK RETURN VOLATILITY DURING HIGH-VISIBILITY EVENTS: EVIDENCE FROM MALAYSIA
}

\author{
Wai-Yan Wong \\ Faculty of Economics and Management, Universiti Kebangsaan Malaysia \\ Chee-Wooi Hooy* \\ School of Management, Universiti Sains Malaysia
}

\begin{abstract}
This study investigates the relationship between political connection and firm stock volatility. We examine whether stock return volatility of politically connected firms differ from non-connected firms during four events. These four events are general election, change of leadership, announcement of government budget, and announcement of policies by the government. This paper uses a volatility event study technique to calculate the abnormal stock return volatility during the four events. We use the data of public-listed firms in Malaysia from 2002 to 2013 . The result shows that political connection is associated with higher stock volatility in certain events. They appear to be the most volatile in the event of general election and least volatile during budget announcement. Besides budget announcement, the other three events showed a stronger volatility as they are considered as more of a surprise announcement rather than scheduled announcement. The paper adds to a limited body of literature investigating the relationship between political connection and market behavior in Malaysia and hopes to show that political connection can impact the stock return volatility of firms during high-visibility events in Malaysia.
\end{abstract}

Keywords: Political connection, stock volatility, Malaysia, event study

Received: 16 December 2019

Accepted: 27 September 2021

https://doi.org/10.33736/ijbs.4314.2021

\section{INTRODUCTION}

The investigation on the issue surrounding political connection and stock return volatility is to see whether firms with political connection can have different stock return volatility as compared to non-connected firms. The effect of political connection on stock return volatility can be seen more clearly during certain events. For example, events like general elections are touted to impact the stock return volatility of politically connected firms more than non-connected firms, regardless of the result of the general election. This is because if the incumbent government wins, stock return of politically connected firms will be boosted. On the other hand, if the incumbent government losses, stock return of politically connected firms will drop drastically. Hence, any result from the

\footnotetext{
- Corresponding author: School of Management, Universiti Sains Malaysia,11800 USM, Penang Malaysia; Tel: +604-653 3889; E-mail: cwhooy@usm.my
} 
general election will have a strong effect on the stock return volatility of politically connected firms.

In order to investigate the impact of political connection on stock return volatility, one should carefully select the events where the impact of political connection can be clearly shown. Past researchers have investigated this issue by investigating on the value and volatility of financial assets during events like elections, electoral systems and policy uncertainty (e.g. Freeman et al., 2000; Leblang \& Bernhard, 2000; Leblang \& Mukherjee, 2004; Blomberg \& Hess, 1997). However, in the context of Malaysia, so far there are very limited studies which have investigated on how some key events can affect the stock return volatility of politically connected firms as compared to non-connected firms in Malaysia. In this study, we investigate how four key events in Malaysia - general election; change in leadership; government budget announcement; and big policy announcements can have important impact of the stock return volatility on politically connected firms. The events of general election and change of country's executive leadership are investigated in this study because they contain high political risk. In general election, the entire cabinet could be changed if the incumbent government loses, therefore firms that establishes connection with the ousted politicians may be experience high volatility. The same situation will happen during the change of country's executive leadership. When a leader steps down, the value of the connection will diminish and this is will cause stock price of politically connected firms to be volatile. By including these 2 events, we can clearly see the impact of political risk on stock volatility. Budget announcement and economic policy announcement are also investigated as it involves the redistribution of resources. During these two events, the government will allocate funds for upgrading infrastructure in the country and for the development of the economy. This redistribution of resources will serve as an opportunity for politically connected firms to gain some benefit and the market expects politically connected firms to receive handouts from the government. As shown by Berry et al. (2010), even in a developed country like the United States, members of Congress who are in the same party as the president are shown to be more privileged during budget announcement. Therefore, we expect their stock volatility of politically connected firms in Malaysia to be high during budget and economic policy announcements.

Political connection can have an effect on stock market volatility due to the perceived benefit that it would receive during these four events. For example, during the events of general elections and change of leadership, we assume the firm volatility of politically connected firms to fluctuate the most as these are uncertain times for political stability and any changes in the political arena will impact politically connected firms more than non-connected firms as their connection maybe lost after the event. For events like government budget and policy announcements, stock return volatility of politically connected firms may also be affected due to the perceived benefits that politically connected firms are receiving. It does not matter if the politically connected firms truly benefit or suffered from the four announcements, what is important in this study is the perception of the market that politically connected firms will be affected and hence the volatility in the stock market return.

The relationship between politics and financial market volatility has been actively explored over the years. This is because when information risk increase, expected return is also expected to increase (Kalay \& Loewenstein, 1985; Bhagat et al., 1987). Therefore, information risk is an undiversifiable risk that is associated with broadcast of the event. The relationship between political connection and stock return volatility is important to be studied because any changes in 
the stability of the political connection will increase the volatility of its stock return, which could possibly alter firm's investment policy. Subsequently, when faced with an increasing volatility, the required return to firm's equity will increase (Clayton et al., 2005). An increasing volatility can also result in a declined desirability of the firm's equity as a medium for acquisitions or compensation. This increase in volatility will persist to be high for a certain duration after event date because even though prices will react instantly to new information, but the full scale of the information will only sink in slowly (Ederington \& Lee, 1993).

Policy decisions can have an effect of volatility during pre and post-announcement period. Neuhierl et al. (2013) investigate how different kinds of announcement affect stock returns, volatility, bidask spreads and trading volume. They find increasing return volatility during the postannouncement period and cited the increasing volatility to higher levels of news-induced valuation uncertainty. Bomfim (2003) finds the conditional volatility of stock market to be low during preannouncement period of monetary policies. Hussain (2011) also reported monetary policies have substantial influence on the volatilities of firm in the U.S. and European markets. Besides that, there are investigations which compare implied volatilities pre- and post-event in order to measure volatility impact. Such papers include Mayhew (1995) and Donders and Vorst (1996). Other related literatures which investigate on volatility patterns during government announcements include French et al. (1989) and Harvey and Huang (1991).

Santa-Clara and Valkanov (2003) find that volatility is higher in a Republican president than a Democrat president in the United States. Volatility is also higher during announcements of negative news compared to positive news (Engle \& Ng, 1993; Chan et al., 2003). Volatility can also be different between different exchange trading locations. For example, Dubofsky (1991) finds that volatility is higher for NYSE stocks compared to AMEX stocks after stock splits.

In a related literature, there is plethora of research which investigates on the impact of corporate events on firm volatility such as major corporate announcements (Brown et al., 1988), earnings announcements (Cornell, 1978), dividend announcements (Kalay \& Loewenstein, 1985), stock splits (Dubofsky, 1991) and stock repurchases (Bartov, 1991).

Our findings show politically connected firms are associated with higher stock volatility during the event of general election and least volatile during budget announcement. During elections, volatility of PCON is higher than non-PCON, particularly PCON_FAM firms. Our result supports Mei and Guo (2004). We postulate that during election, investors will gather evidence to evaluate the skill of the newly appointed Cabinet and this generally leads to a period of higher volatility as investors update their ability estimates and revalue the connected firms. On the other hand, stock volatility of PCON firms is the lowest during budget announcement. The reason could be because budget announcement is considered a scheduled announcement as it happens once a year, and therefore contains the least level of surprise element for investors. These results will have implications on the investment decision of investors due to the perceived stock volatility during these events.

This study contributes to the existing literature and investors by showing the significance of certain events on the stock volatility of politically connected firms. The existing literature focused on the impact of these events on the cumulative abnormal returns (CAR) of connected firms, with less emphasis on cumulative abnormal volatility (CAV). Studying firm volatility is equally important 
as firms with higher volatility is perceived as having higher risk. This will affect risk-averse investors as they typically shun firms with high stock volatility. Additionally, many investors hold a high percentage of their stock portfolios of their home country (Baxter \& Jermann, 1997) and we believe Malaysian investors are of no exception. As such, the home country's political risk should have implications on investor's risk portfolios. This study investigates the riskiness of politically connected firms during important events in Malaysia and thus provides Malaysian investors with some indication on whether they should invest in firms that are politically connected through any of the four events this study examines.

The remainder of this paper is organized as follows. Section 2 presents the literature in the area of political connection and firm stock volatility for each of the four events. The hypotheses statement will also be presented here. Section 3 discusses about the sample and methodology. Section 4 provides the result and discussion of the findings. Section 5 presents the conclusion.

\section{LITERATURE REVIEW AND HYPOTHESES DEVELOPMENT}

\subsection{Election and Political Uncertainty on Stock Market Volatility}

A large and growing body of literature has examined the association between election and stock market volatility. Many studies agree that the former have a significant impact on the latter. However, many of the studies done focuses on developed countries with lesser emphasis on emerging markets.

In 1991, Granberg and Holemberg published a paper which investigates the effect of election in Sweden and United States. They found increased stock market volatility in Sweden but not in the United States during election period. In an analysis of political election on market volatility in emerging countries, Mei and Guo (2004) also reported increasing market volatility. Their results also reported the occurrence of financial crisis happened mostly during those periods. Later on in Bialkowski et al. (2008) conducted a more comprehensive study on 27 OECD countries to determine the effect of elections on stock market volatility. Their result supports the notion that throughout the week surrounding election, variance will certainly be twofold more than usual which imply that investors are taken aback by the result of the election. Numerous issues, like government's modification of political direction, absence of obligatory polling rules, a slim margin of win or the inability to create a government with a two third chairs considerably add to the scale of the election surprise. Additionally, there is also proof which show that markets with less trading history showed stronger response.

In a more recent study, Opare (2012) also examine the volatility of stock markets in 13 European countries around political election for the years 1990 to 2012. The author found increasing volatility during pre-election periods and it soars in days nearer to election day. Besides that, the author also found higher-than-normal volatility during post-election period. Although there is only a temporary increase in volatility but the hike is found to be significant. Other than that, Goodell and Vahamaa (2013) also dwelled into the same issue but in the setting of US presidential election. They found that stock market unpredictability rises with clear development in the likelihood of victory of the ultimate front-runner. These conclusions imply that the presidential election procedure stimulates market nervousness as investors establish and alter their confidence 
concerning upcoming macroeconomic policy. In another different but relevant study, Fails (2014) demonstrates that market seems to be less volatile when an autocratic political leader is selected in a country rather than a democratic leader. The reason being a democratic regime is more prone to political turnover and therefore results in higher political risk and this in turn causes higher market volatility.

Lately, there has been a growing quantity of works on the influence of political uncertainty on market volatility. Political uncertainty deserves more attention because in reality election is just a subset of political uncertainty. Political uncertainties include events like change of Prime Minister outside of election period and during political unrest. Boutchkova et al. (2012) identified the political uncertainty as a cause for market volatility. Their results show that although national political uncertainty is associated with systematic volatility, but international political threats are related with larger idiosyncratic volatility. Some industries such as those which are extra dependent on contract implementation, trade and labour will be more sensitive to political events compared to others.

This topic is further emphasized when Pastor and Veronessi (2013) created a model of common equilibrium for the decision of policy implementation by government where stock prices respond to governmental information. The authors determine that a risk premium is required during political uncertainty and the premium is higher during weaker economic settings. Thus, political uncertainty causes stocks to be extra volatile and it also decreases the value which the government provides to the market and it also makes stocks more volatile, particularly during the period of weak economy. In response to recent studies being made on this topic, Chau et al. (2014) inspect the influence of political uncertainty on the volatility of major stock markets in the Middle East and North African (MENA) region. The authors backed the idea that political uncertainty adds to financial volatility. Therefore, it contributes to the perception of how political uncertainty play a part on stock market stability and this is greatly valued by investors and market regulators in the MENA region.

In the case of Malaysia, Liew and Rowland (2016) shown that the FBMKLCI index increased by 62.52 points a day after elections in Malaysia. Lean and Yeap (2016) also shown that the key index of FTSE Bursa Malaysia KLCI experienced significant volatility during Malaysia's general election years. Prior to the 2004 general election, there are no perceived danger to the incumbent government to retain their power. However, the election outcomes in years 2004, 2008, and 2013 are more unpredictable as compared to previous elections due to a stronger opposition party. During the change of the country's executive leadership, there will be uncertainty regarding the existing policies that was implemented by the outgoing leader. The new leader may change the trajectory and direction the country is heading to. There might be changes to economic and financial policies that may cause uncertainty to the market and investors. For example, the fourth Prime Minister of Malaysia focused on achieving the 2020 Vision. The fifth Prime Minister focused on agriculture industry and establishing Economic Corridors. The sixth Prime Minister focused on the National Transformation 2050. As such, we predict the stock market volatility surrounding elections and political uncertainty in Malaysia to be high. The below hypotheses are constructed:

\section{H1: There is a positive relationship between politically connected firms and firm volatility during} general election. 
H2: There is a positive relationship between politically connected firms and firm volatility during the change in country's executive leadership.

\subsection{Government Budget on Stock Market Volatility}

Government budget is a manuscript that states a government's planned incomes and expenditures for the forthcoming economic year. It normally has a technical, political and economic intention. In contrast with an economic budget, government budget is not completely constructed to distribute limited resources for best economic usage. Political intention has its place in a government budget where many sides will influence it as much as possible so that they will have more advantages and have less issues. Meanwhile, the technical perspective which was mentioned just now is the prediction of the amount of income and expenditure. It is surprising to note that even though government budget has such influences on the economy, not many studies are being done to examine its effect on the stock market.

One of the few includes Oliveira (2014) who examines the effect of government budget on the stock market performance in Portugal using the data from 1998 to 2013. The author reiterates the importance of studying the impact government budget on market because it reveals the future expenses and revenues which in turn is going to foresee the economic and financial condition of a country. Her result suggests that government budget announcement have a positive effect on the basic materials and consumer services sector in Portugal. Consumer services sector also appear to be experience high volatility during the time period.

In the context of Malaysia, as reported by Lim (2019) and Idris (2018), the FBMKLCI tends to be more volatile during the period surrounding the budget announcement. In particular, investors are usually holding back ahead of the budget which will cause the KLCI to be flat. In the period after the budget announcement when investors are certain about the direction of the government for the next one year, the former will then start to invest again. Therefore, stock volatility will increase. Investors are also concerned whether the government will revise the existing tax rates and introduce new taxes due to the lack of revenue (Winifred \& Perez, 2018).

Although there are limited empirical evidences which investigates this particular event, this study believe that stock market will experience increased volatility during budget announcement, particularly politically connected firms. This is because investors will try to capitalize on the possible increase in stock return of firms in Malaysia. As such, the below hypothesis is constructed:

\section{H3: There is a positive relationship between firms which are politically connected and firm volatility during budget announcement.}

\subsection{Economic Policy Announcement on Stock Market Volatility}

On the other hand, researches are more interested in studies about how changes in government policies affect stock market. Most studies would agree that change in government policies will cause stock market to be more volatile because investors are perceived to be more risk-adverse and any change to the status quo will be less favoured. For example, Hermes and Lensink's (2001) paper on policy uncertainty on inflation level, consumption of government, tax expenditures and budget deficits are found to be impact of stock market. Their argument lies in the perception of 
investors on government's unclear policy direction which will result in capital flight and therefore a more volatile market.

Another study by Vahamaa and Aijo (2011) observes how volatility is affected by the Fed's monetary policy. Their result shows positive correlation between implied volatility and policy shocks. However, they are caused by the volatility-reducing effects of undesirable shocks. Additionally, the authors commented that implied volatility is afflicted by both planned and unplanned policy activities, where planned policy shocks have a more profound influence on volatility. Finally, their results showed that monetary policy decisions have a larger influence on implied volatility in the stages of expansive policy.

Pastor and Veronessi (2012) agree that modification in government policy influence stock prices. The authors' exemplary equilibrium model covers two issues. Firstly, it is when the choices of government have both economic and noneconomic intentions and secondly, is the government's policy indecision. The model assumed several empirical forecasts. They postulated that stock prices will decrease during disclosure of policy amendment. Nonetheless, the decrease in price should be large if there is high ambiguity about a government policy, and if the policy amendment is before a brief or slight recession in economic. The authors argue that policy amendment will cause volatilities to be greater.

In another study to measure the impact of economic policy uncertainty, Brogaard and Detzel (2015) discovered that when ambiguity about economic policy rises by one percent, there will be a decrease of 2.9 percent in market returns followed by a rise of 18 percent in market volatility for 21 nations. Their outcomes show that indeterminacy in government economic policymaking has substantial and enduring effect on real and financial consequences. Boutchkova et al. (2012) investigate the impact of national and international political risks on the return volatility of trade. The authors concluded that businesses which are extra reliant on trade, contract implementation, and labour display larger return volatility at what time when national political risks are higher. Another study by Suleman (2014) also looked into the issue of political risk on market volatility. The results confirm that equity market returns and volatilities respond significantly to political risk. However, respond is lesser in developed countries in Asia.

In the case of Malaysia, the announcement of economic policies will affect the stock volatility of connected firms more than non-connected firms as the former is postulated to benefit from the disbursement of projects. There is no precedent literature regarding this particular topic in the context of Malaysia and we can only formulate our hypothesis on the basis of the rent-seeking theory which states that firms will tend to lobby for government projects and subsidies by providing some kickbacks in return. Malaysia do not have a system that records electoral funding like in the United States and thus, the contributions that is made by businessperson to politicians during elections is unknown. It is possible that politicians that wins the election might reward the businessperson who supports him through these economic projects. As such, the below hypothesis is constructed:

H4: There is a positive relationship between firms which are politically connected and firm volatility during the announcement of economic policies. 
Investigation of volatility is common in the area of financial research. Politically connected firm will cease to be more volatile when faced with political uncertainty. All the four events specified in this study are expected to affect firm's stock volatility and in turn, this will affect firm's performance because when faced with increasing volatility, the required return to firm's equity might increase. The methodology of this study is discussed in the next chapter.

\section{METHODOLOGY}

\subsection{Data description}

The study deploys data of firms listed on the Main Market of Bursa Malaysia. The sample frame for this study covered the period from 2002 - 2013. Financial and share price data are taken from the Datastream and annual reports. Data of politically connected firms in this study is taken from Wong and Hooy (2018) and they are presented in Table 1. PCON_GLC are government-linked companies with the majority shareholder being a government-linked investment companies (GLIC). There is a total of 29 firms that falls in this category. PCON_BOARD are firms with politically connected board of directors and a total of 191 firms fits this criterion. PCON_BUS are firms with founders or business owners having close relationship with the leading politicians. This data is initially gathered from Gomez and Jomo (1997) and further updated. A total of 22 firms falls into this category. PCON_FAM are firms with the immediate family members of the leading politician holding shares or serving in its board of directors. A total of 14 firms fits this criterion. Non-PCON firms are firms that does not fall into any of the four PCON criteria. Events included in this study follows Wong (2016) and they are presented in Table 2.

Table 1: Background of the types of political connection from 2002 to 2013.

\begin{tabular}{lll}
\hline \hline Types of political connection & No. of firms & Percentage (\%) \\
\hline PCON_GLC & 29 & 7.71 \\
PCON_BOARD & 191 & 50.80 \\
PCON_BUS & 22 & 5.85 \\
PCON_FAM & 14 & 3.73 \\
NON-PCON & 120 & 31.91 \\
\hline Total & 376 & 100.00 \\
\hline \hline
\end{tabular}

Notes: PCON_GLC denotes firm which is politically connected through government-linked company; PCON_BOARD denotes firm which is connected through board of director; PCON_BUS denotes firm which is connected through businessman; PCON_FAM denotes firm which is politically connected through family member. NON-PCON denotes firm which are not politically connected.

Table 2: Type of events and their respective dates

\begin{tabular}{cll}
\hline \hline No. & Event & Date \\
\hline & Panel A: Election & \\
1 & 2013 general election & $5 / 5 / 2013$ \\
2 & 2008 general election & $8 / 3 / 2008$ \\
3 & 2004 general election & $21 / 3 / 2004$
\end{tabular}




\begin{tabular}{|c|c|c|}
\hline No. & Event & Date \\
\hline & Panel B: Change of leadership & \\
\hline 1 & Sworn-in of the $6^{\text {th }}$ Prime Minister & $3 / 4 / 2009$ \\
\hline \multirow[t]{2}{*}{2} & Sworn-in of the $5^{\text {th }}$ Prime Minister & $31 / 10 / 2003$ \\
\hline & Panel C: Budget announcement & \\
\hline 1 & 2013 budget announcement & 28/9/2012 \\
\hline 2 & 2012 budget announcement & $7 / 10 / 2011$ \\
\hline 3 & 2011 budget announcement & $15 / 10 / 2010$ \\
\hline 4 & 2010 budget announcement & $23 / 10 / 2009$ \\
\hline 5 & 2009 budget announcement & $29 / 8 / 2008$ \\
\hline 6 & 2008 budget announcement & $7 / 9 / 2007$ \\
\hline 7 & 2007 budget announcement & $1 / 9 / 2006$ \\
\hline 8 & 2006 budget announcement & $30 / 9 / 2005$ \\
\hline 9 & 2005 budget announcement & $10 / 9 / 2004$ \\
\hline 10 & 2004 budget announcement & $12 / 9 / 2003$ \\
\hline \multirow[t]{2}{*}{11} & 2003 budget announcement & $20 / 9 / 2002$ \\
\hline & Panel D: Economic policy announcements & \\
\hline 1 & Iskandar Malaysia & $8 / 11 / 2006$ \\
\hline 2 & Northern Corridor Economic Region (NCER) & $30 / 7 / 2007$ \\
\hline 3 & East Coast Economic Region (ECER) & $30 / 10 / 2007$ \\
\hline 4 & Sabah Development Corridor (SDC) & $29 / 1 / 2008$ \\
\hline 5 & Sarawak Corridor of Renewable Energy (SCORE) & $11 / 2 / 2008$ \\
\hline 6 & New Economic Model & $11 / 6 / 2012$ \\
\hline 7 & Government Transformation Programme (GTP) & $28 / 1 / 2010$ \\
\hline 8 & $9^{\text {th }}$ Malaysia Plan & $31 / 3 / 2006$ \\
\hline 9 & $10^{\text {th }}$ Malaysia Plan & $10 / 6 / 2010$ \\
\hline 10 & 1Malaysia Development Berhad (1MDB) & $30 / 9 / 2009$ \\
\hline
\end{tabular}

Note: Date is in DD/MM/YYYY format.

\subsection{Volatility measurement}

The impact of events on the stock return volatility can be determined by using a volatility eventstudy approach. The analysis follows the work of Bialkowski et al. (2008). It starts with segregating the firm-specific component of variance within a $\operatorname{GARCH}(1,1)$ framework:

$$
\begin{aligned}
& R_{i, t}=\alpha+\beta R_{t}^{*}+\varepsilon_{i, t}, \varepsilon_{i, t} \sim N\left(0, h_{i, t}\right) \\
& h_{i, t}=\gamma_{1} h_{i, t-1}+\gamma_{2} \varepsilon_{i, t-1}^{2}
\end{aligned}
$$

where $R_{i, t}$ and $R_{t}^{*}$ are the compounded returns on Malaysia's stock market in firm $i$ and the Kuala Lumpur Composite Index (FBMKLCI) on day $t$, respectively. $\varepsilon_{i, t}$ denotes the firm-specific part of the index returns, and $h_{i, t}$ stands for its conditional variance.

Equation (1) and (2) are estimated together using the Maximum Likelihood method in the estimation period window. This study follows Brown and Warner (1985) in determining the length of the estimation period, which is 250 days preceding the event window in order to estimate the benchmark model. The specification of volatility event window is 11 days, following the asymmetric event window of $(-5,+5)$ for the four events studied. 
In measuring abnormal volatility, the variation in $\varepsilon_{i, t}$ around the event date in relation to its regular non-event level is calculated. The GARCH model serves as a benchmark, as it can provide an indication of what the volatility would have been, had the event not occurred.

The abnormal percentage change in volatility on any day t of the event window is $\left(\widehat{M}_{t}-1\right)$. For an event window $\left(n_{1}, n_{2}\right)$, the cumulative abnormal volatility (CAV) can be calculated as

$$
\operatorname{CAV}\left(n_{1}, n_{2}\right)=\left(\sum_{t=n 1}^{n 2} \widehat{M}_{t}\right)-\left(n_{2}-n_{1}+1\right)
$$

where $\widehat{M}_{t}$ can be calculated as the cross-sectional variance of demeaned residuals.

The volatility series are then plotted into graph for comparison purposes.

We also test for the CAVs' statistical significance. To do that, we use the null hypothesis $\left(H_{0}\right)$ to indicate no cumulative abnormal return within the event window. On the other hand, the alternative hypothesis $\left(H_{1}\right)$ indicate that the existence of cumulative abnormal return within the event window. If critical value of the test statistics is more than $10 \%$, the null hypothesis will be rejected. They are stated as below:

$$
\begin{aligned}
& H_{0}: \mu=0 \text { and } H_{1}: \mu \neq 0 \\
& t(C A V)=\frac{\operatorname{CAV}\left(t_{1}, t_{2}\right)}{\sigma^{2}\left(t_{1}, t_{2}\right)}
\end{aligned}
$$

where $\sigma^{2}\left(t_{1}, t_{2}\right)=L \sigma^{2}\left(A V_{t}\right) . L$ is the length of the event period which can be calculated from $t_{2}-t_{1}+l$, which is 11 trading days.

\section{RESULTS}

\subsection{General election}

Figure 1 shows the comparison of the average volatility of all politically connected firms (PCON) and non-politically connected firms (non-PCON) during general election. The volatility for PCON is higher than non-PCON during the event day. In the days before and after the event, the stock volatility for both types of firms seem to fluctuate only a little.

This study further separates PCON into four different types. They are government-linked companies (PCON_GLC), firms connected through board of directors (PCON_BOARD), firms connected through businessmen (PCON_BUS) and firms connected through family members (PCON_FAM). The results are presented in Figure 2. An analysis on the volatility of the differing politically connected firms showed certain types of firms are slightly more volatile than the others. Generally, volatility is lower before general election but increases tremendously during the event date. In the period after the event, volatility continue to be higher for certain types of PCON, particularly PCON_FAM firms. Our result echo those from Opare (2012) which saw increasing volatility during the pre-event window. Similarly, our result also coincides with the result of Mei and Guo (2004) which reported increasing market volatility during an event. Other examples include the period surrounding President Clinton, Bush and Obama election in the United States, where it recorded an increased stock market volatility (eg: Goldman et al., 2009). In a study of 33 
countries during their respective elections, Pantzalis et al. (2000) also found higher volatilities 2weeks leading to the event. Similarly, Bialkowski et al. (2008) found general elections cause stock market to be more volatile in a sample of 27 OECD nations. This is because following the result of a general election, investors will gather evidence to evaluate the skill of the newly appointed Cabinet and this generally leads to a period of higher volatility as investors update their ability estimates and revalue the firms. As firms which are politically connected have higher volatility during general election, thus hypothesis 1 is supported. The results from this study also showed that stock volatility of PCON and non-PCON is the highest during general election as compared to the other three events investigated in this study. This imply that market has a lot of uncertainty during election as they are afraid of a change in the incumbent government as it would create a lot of instability in the country. Therefore, investors should take precaution during general elections in Malaysia as it is a period of high volatility.

Figure 1: Volatility of PCON and NON-PCON firms during general election.

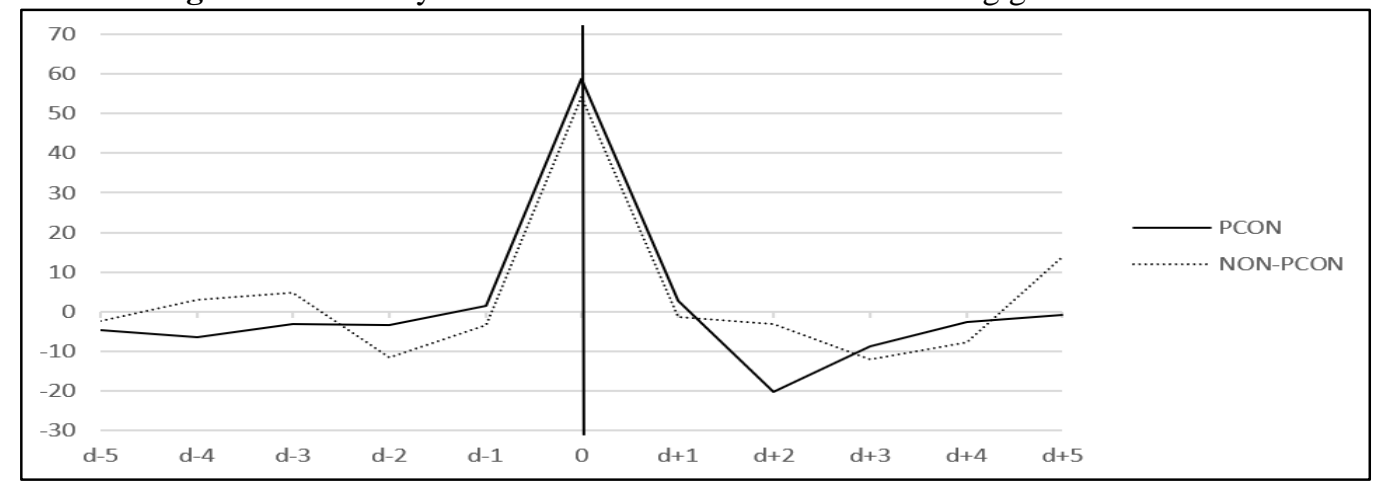

Figure 2: Volatility of PCON_GLC, PCON_BOARD, PCON_BUS, PCON_FAM and NONPCON firms during general election.

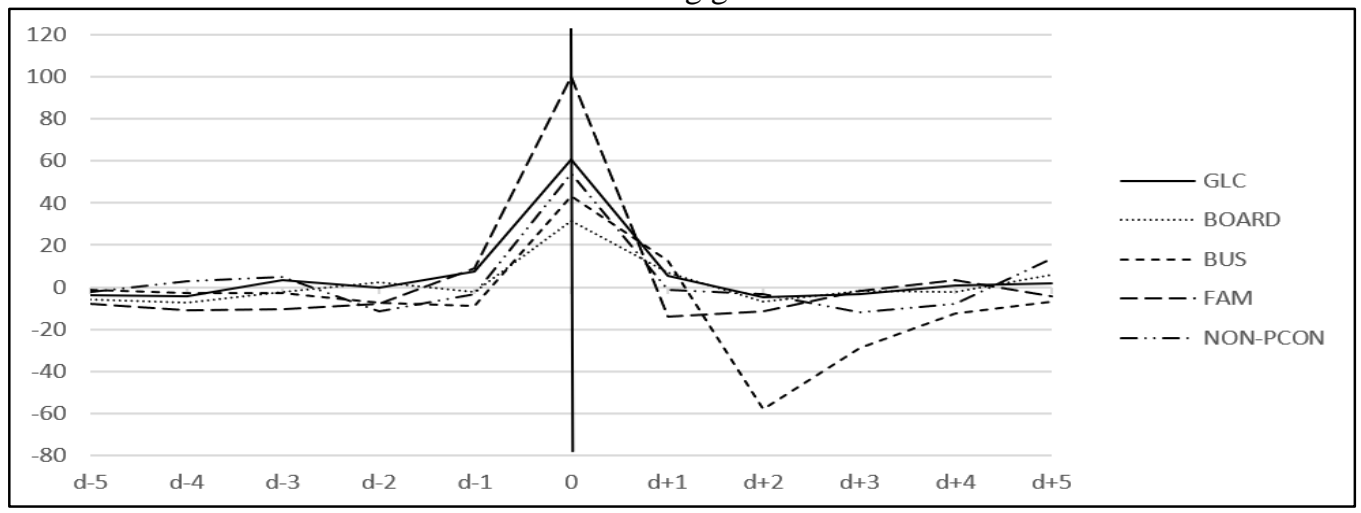




\subsection{Political uncertainty during the change of leadership}

Figure 3 shows the comparison of the average volatility of all politically connected firms (PCON) and non-politically connected firms (non-PCON) during change of leadership. The volatility between PCON and non-PCON is quite similar in the entire event windows of 61 days. On the event day itself, the stock market is not as volatile as during general election.

Figure 4 shows the volatility for PCON when separated out into PCON_GLC, PCON_BOARD, PCON_BUS, and PCON_FAM. The result shows that PCON_BOARD firms experience high volatility during the event day itself, and also between three to four weeks after the event day. The stock volatility of other types of PCON firms are almost similar with non-PCON firms.

The result of this study shows that Malaysia's stock market does not experience high volatility during leadership transition compared to other countries. Although Malaysia's stock market does experience high volatility during this event, but firms which are politically connected through PCON_BOARD firms experience higher volatility than those of non-connected firms. Generally, we support the result by Lin and Wang (2007) who shown that shift in the political regime in Japan's does not increase its stock market volatility. On the other hand, our result does not support Wang et al. (2008) who found evidence that political change has an inverse relationship with stock market in developed countries.

The change in the political leadership may affects markets by adding uncertainty around future policy, and therefore increasing the future cost and gain for investors which will lead to lower returns and higher volatility in periods around when the executive leadership of a country is changed. The result from this study denotes that stock prices are moderately volatile during the event of leader transition. As only PCON_BOARD firms have higher volatility during change of leadership, thus hypothesis 2 is partially supported.

Figure 3: Volatility of PCON and NON-PCON firms during change in country's executive

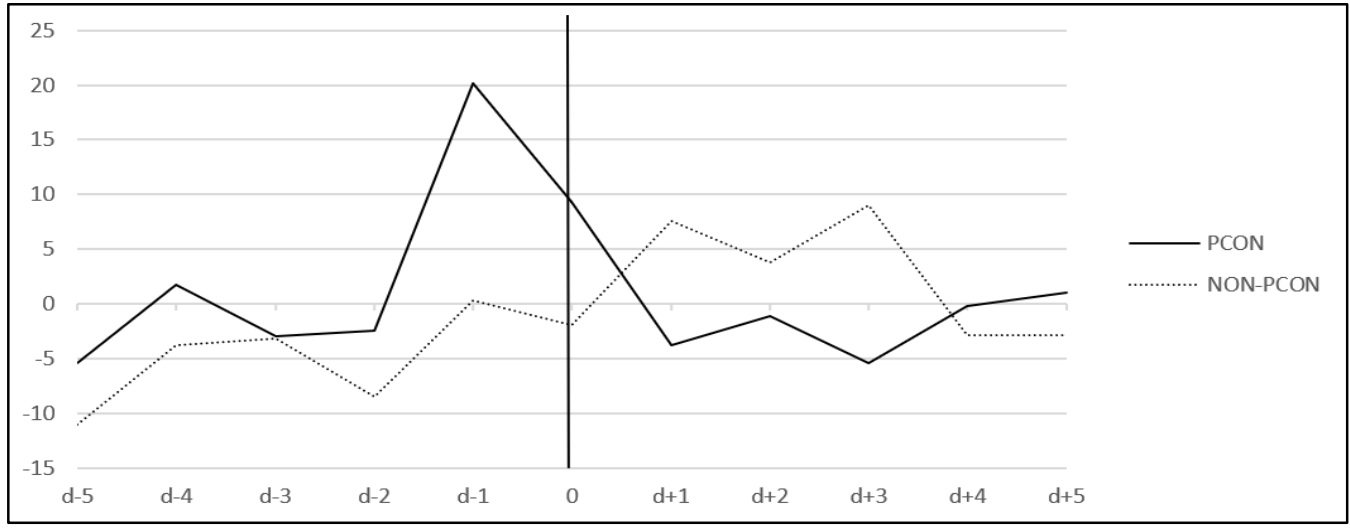


Figure 4: Volatility of PCON_GLC, PCON_BOARD, PCON_BUS, PCON_FAM and NONPCON firms during change in country's executive leadership.

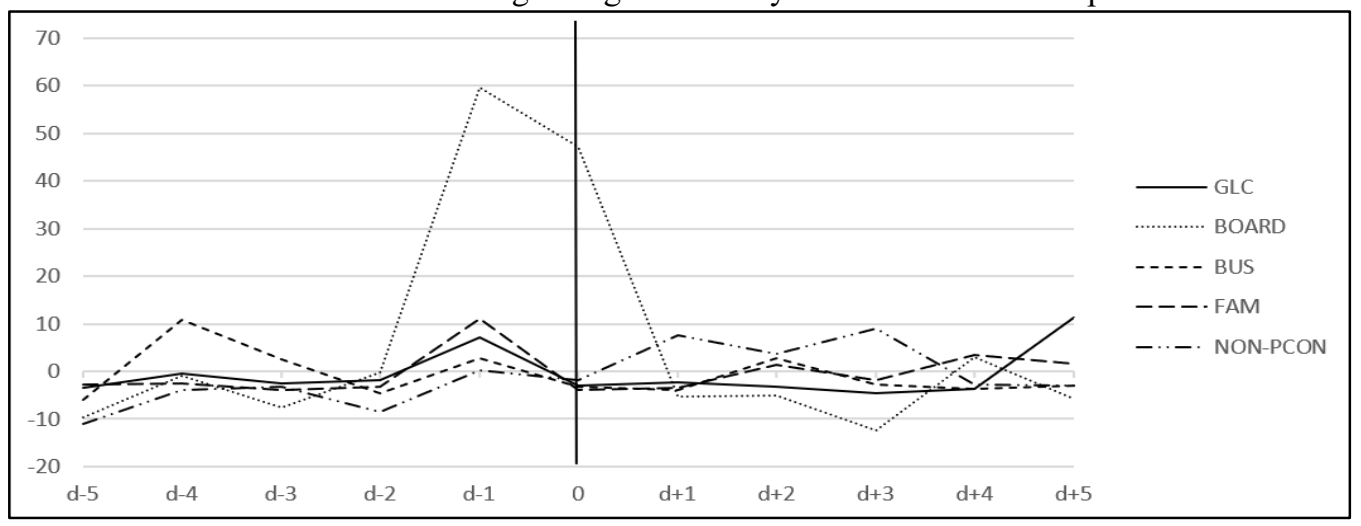

\subsection{Budget Announcement}

Figure 5 shows the comparison of the average volatility of all politically connected firms (PCON) and non-politically connected firms (non-PCON) during budget announcement. The volatility for both PCON and non-PCON is very low during budget announcement and both move in quite a similar way for the entire event window. Even on the event day itself, there is no high volatility. Figure 6 shows the volatility for PCON when separated out into PCON_GLC, PCON_BOARD, PCON_BUS, and PCON_FAM. The result shows that PCON_BUS and PCON_FAM firms experience higher volatility before and after the budget announcement.

The event of budget announcement does not seem to have much effect on the emotion and psychological welfare of investors as volatility during pre-event does not differ much from those during post-event. The finding in this section do not support hypothesis 3 which expects the stocks of politically connected firms to be more volatile compared to those not connected. As such, hypothesis 3 is rejected. Therefore, the result of this study does not support the conjecture by Lim (2019) and Idris (2018), who mentioned that the FBMKLCI tends to be more volatile during the period surrounding the budget announcement. In fact, the budget announcement recorded the lowest CAV as compared to the other three events investigated in this study. This could imply that the market is not anxious about the budget's content as they mainly focus on improving the livelihood of the citizens of the country. 
Figure 5: Volatility of PCON and NON-PCON firms during budget announcement.

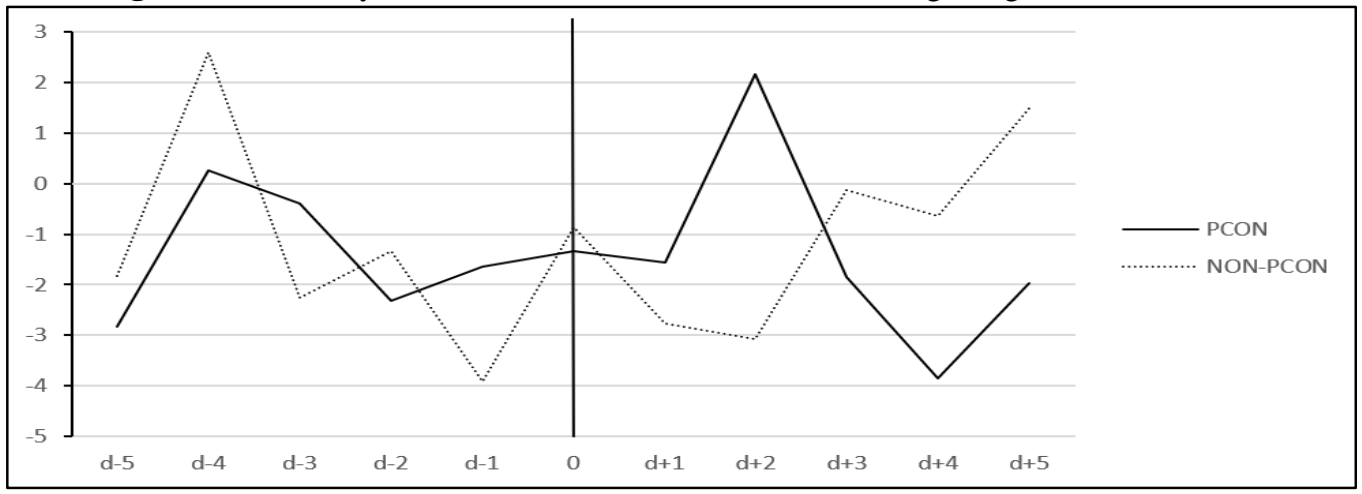

Figure 6: Volatility of PCON_GLC, PCON_BOARD, PCON_BUS, PCON_FAM and NONPCON firms during budget announcement.

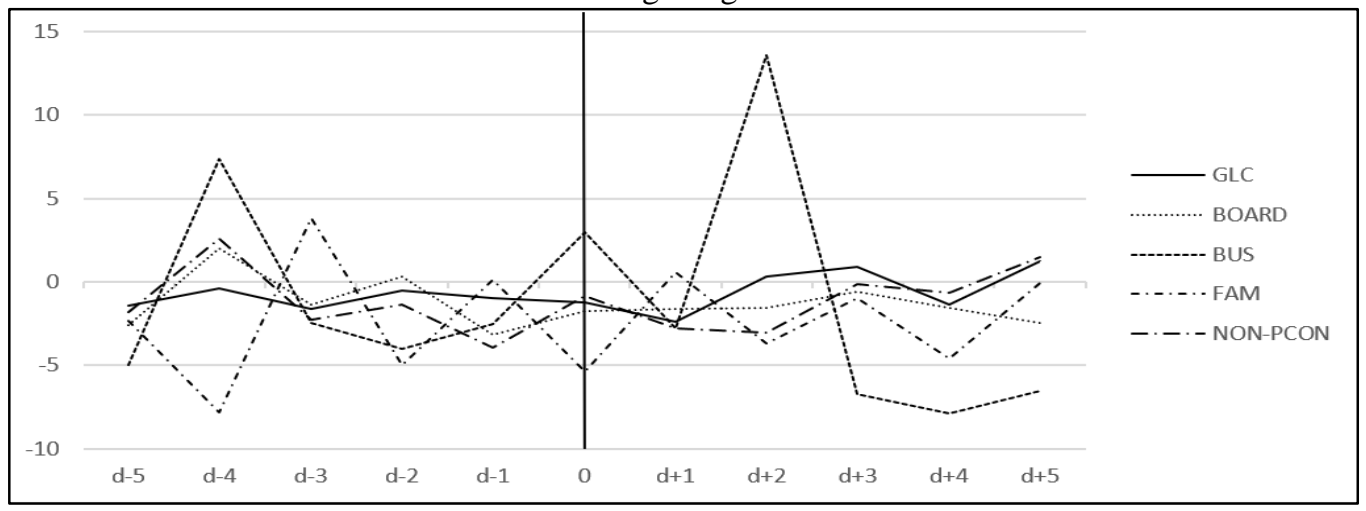

\subsection{Economic Policy Announcement}

Figure 7 shows the comparison of the average volatility of all politically connected firms (PCON) and non-politically connected firms (non-PCON) during economic policy announcement. Although the volatility for both PCON and non-PCON fluctuates quite a bit 5 days before and after the event date, their movement of both PCON and non -PCON is quite identical to each other. Figure 8 shows the volatility for PCON when separated out into PCON_GLC, PCON_BOARD, PCON_BUS, and PCON_FAM. The result is almost identical to Figure 7. This result does not support the existing literatures like Vahamaa and Aijo (2011) and Pastor and Veronessi (2012) which document that a change in government policies will cause stock market to be more volatile because investors are perceived to be more risk-adverse and changes to the status quo will be less favoured. As the result from this finding indicate that politically connected firms do not experience higher volatility than those of non-connected firms, therefore hypothesis 4 is rejected. This result also implies that investors in the Malaysian stock market does not anticipate the announcement of economic policies to benefit connected firms more than non-connected firms, hence the lackluster reaction Also, when compared among the four types of PCON, no PCON stand out in terms of its 
CAV. The fluctuations of the CAV are also lower as compared to events like general elections and change in leadership. This shows that modification in government policy does influence stock prices and impose no substantial risk to firms in Malaysia as compared to other countries like the United States.

Figure 7: Volatility of PCON and NON-PCON firms during announcement of economic policies.

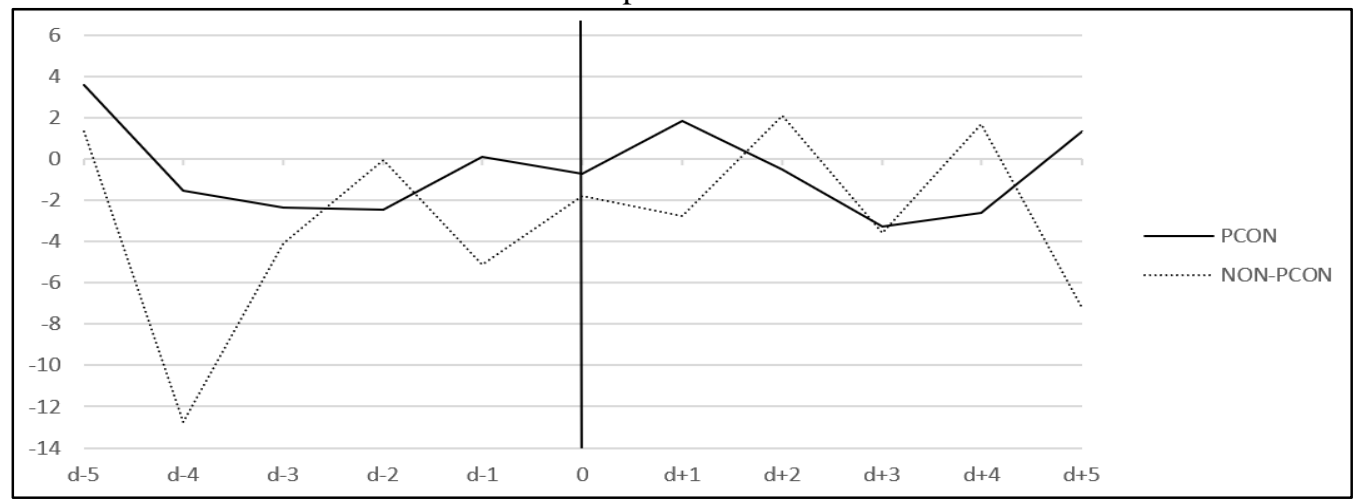

Notes: Y-axis represents cumulative abnormal volatility. X-axis represents the event window where d-30 is 30 days before the event date, 0 is the event date, and $\mathrm{d}+30$ is 30 days after the event.

Figure 8: Volatility of PCON_GLC, PCON_BOARD, PCON_BUS, PCON_FAM and NONPCON firms during announcement of economic policies.

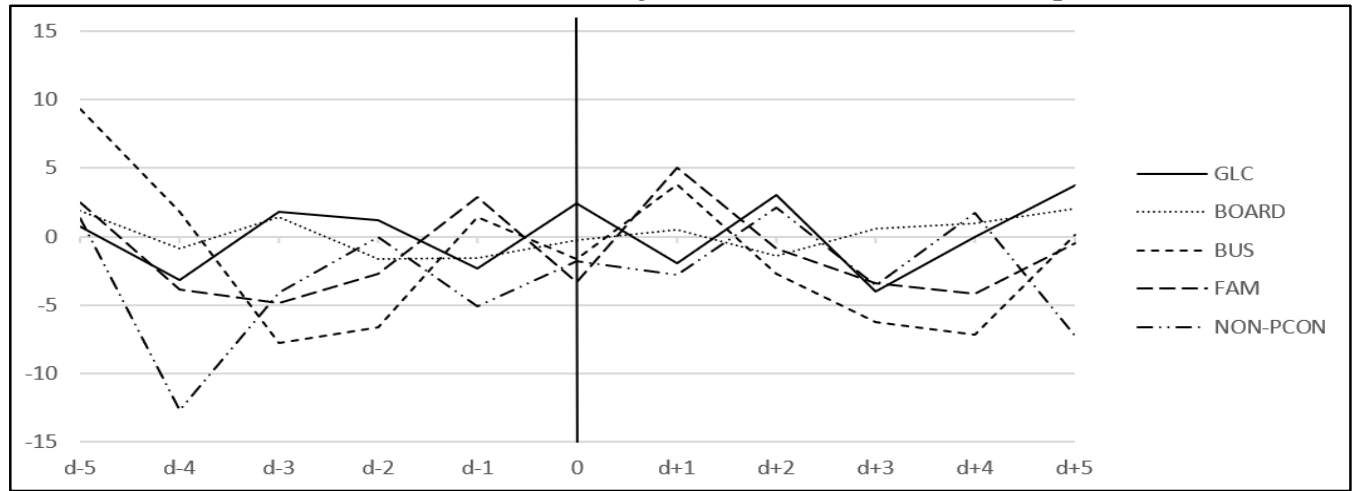

Notes: Y-axis represents cumulative abnormal volatility. X-axis represents the event window where d-30 is 30 days before the event date, 0 is the event date, and $d+30$ is 30 days after the event.

\subsection{Univariate test}

In this univariate test, we test whether the CAV for the four types of PCON is significantly different from non-PCON. The results in Table 3 supports our earlier results that the stock market experience higher volatility in events like election but not during budget or economic policy announcements. The difference of CAV between the different types of PCON and non-PCON also shows only 
PCON like PCON_GLC and PCON_FAM has higher CAV as compared to non-PCON during the event of general election. During the event of leadership change, PCON_BOARD have CAV that is statistically different from non-PCON, which supports our result in Figure 4. Whereas in certain events like budget announcement, all the PCON do not have CAV that is statistically different from non-PCON, which also supports our earlier result in Figure 6 and 8.

Table 3: Univariate tests between the four types of politically connected firms and nonconnected firms during the four events.

\begin{tabular}{lllll}
\hline \hline & General election & $\begin{array}{l}\text { Change in } \\
\text { executive } \\
\text { leadership }\end{array}$ & Budget & $\begin{array}{l}\text { Economic } \\
\text { policy }\end{array}$ \\
\hline PCON_GLC & $1.98^{* *}(0.03)$ & $-0.37(0.19)$ & $0.90(0.45)$ & $-0.54(0.17)$ \\
Non-PCON & $1.87 *(0.08)$ & $0.94(0.34)$ & $0.56(0.13)$ & $-0.37(0.16)$ \\
Difference & $0.11(0.34)$ & $1.31(0.13)$ & $0.34(0.11)$ & $-0.17(0.50)$ \\
& & & & \\
PCON_BOARD & $1.27 *(0.09)$ & $2.56^{* *}(0.07)$ & $1.14(0.98)$ & $-0.87(0.23)$ \\
Non-PCON & $1.06 *(0.05)$ & $0.60(0.18)$ & $0.67(0.80)$ & $-1.16(0.65)$ \\
Difference & $0.21(0.71)$ & $1.96^{* * *(0.00)}$ & $0.47(0.27)$ & $0.29(0.81)$ \\
& & & & \\
PCON_BUS & $1.52(0.29)$ & $0.99(0.51)$ & $0.32(0.11)$ & $-0.86(0.14)$ \\
Non-PCON & $1.69 *(0.08)$ & $0.47(0.70)$ & $0.77(0.63)$ & $0.06(0.73)$ \\
Difference & $-0.17(0.25)$ & $0.52(0.84)$ & $-0.45(0.57)$ & $-0.92(0.82)$ \\
& & & $1.16(0.19)$ & $-0.29(0.85)$ \\
PCON_FAM & $1.35 * *(0.01)$ & $1.39(0.11)$ & $0.95(0.35)$ & $0.14(0.61)$ \\
Non-PCON & $1.90 *(0.06)$ & $1.79(0.23)$ & $0.21(0.29)$ & $-0.43(0.18)$ \\
Difference & $-0.55(0.42)$ & $-0.40(0.36)$ & \\
\hline \hline Notes $* * *$ and $* * *$ denote statistical significance at the $10 \%, 5 \%$, and $1 \%$ levels. &
\end{tabular}

\section{CONCLUSION}

According to Civilize et al. (2015), stock market has the natural ability in showcasing informational efficiency. As such, if political connection is perceived to contain any value during the onset on certain political or economic events, the stock market should also be able to reflect this value. it should also reflect the effect of political connection on firm's value. Using the dataset from Malaysia, this study shows that political connection is associated with higher stock volatility in certain political and economic events. Based on the findings in this section, we can conclude that stock price appears to be the most volatile in the event of general election and least volatile during budget announcement. The reason could be because stock market tends to be quieter and less volatile during the period of scheduled policy announcements compared to period of surprise announcements (Bomfim, 2003). Budget announcement is considered a scheduled announcement as it happens once a year. The other events however, show a stronger volatility in the short-run as they are considered as more of a surprise announcement rather than scheduled announcement. 


\section{ACKNOWLEDGEMENT}

We thank Geran Inisiatif Penyelidikan (GIP) FEP 2021 [UKM.FEP.SPI.800-1/3] for funding this research. The authors declare that there is no conflict of interest.

\section{REFERENCES}

Bartov, E. (1991). Open-market stock repurchases as signals for earnings and risk changes. Journal of Accounting and Economics, 14(3), 275-294.

Baxter, M. \& Jermann, U. J. (1997). The international diversification puzzle is worse than you think. American Economic Review, 87, 170 - 180.

Berry, C. R., Burden, B. C., \& Howell, W. G. (2010). The president and the distribution of federal spending. American Political Science Review, 104(4), 783-799.

Bhagat, S., Brickley, J. A., \& Loewenstein, U. (1987). The pricing effects of interfirm cash tender offers. The Journal of Finance, 42(4), 965-986.

Bialkowski, J., Gottschalk, K., \& Wisniewski, T. P. (2008). Stock market volatility around national elections. Journal of Banking \& Finance, 32(9), 1941-1953.

Blomberg, S. B., \& Hess, G. D. (1997). Politics and exchange rate forecasts. Journal of International Economics, 43(1), 189-205.

Bomfim, A. N. (2003). Pre-announcement effects, news effects, and volatility: Monetary policy and the stock market. Journal of Banking \& Finance, 27(1), 133-151.

Boutchkova, M., Doshi, H., Durnev, A., \& Molchanov, A., (2012). Precarious politics and return volatility. Review of Financial Studies, 25(4), 1111-1154.

Brogaard, J., \& Detzel, A. (2015). The Asset-Pricing Implications of Government Economic Policy Uncertainty. Management Science, 61(1), 3-18. https://doi.org/10.1287/mnsc.2014.2044

Brown, K. C., Harlow, W. V., \& Tinic, S. M. (1988). Risk aversion, uncertain information, and market efficiency. Journal of Financial Economics, 22(2), 355-385.

Brown, S. J., \& Warner, J. B. (1985). Using daily stock returns: The case of event studies. Journal of Financial Economics, 14(1), 3-31.

Chan, D., Kohn, R., \& Kirby, C. (2003). Multivariate stochastic volatility with leverage. (Unpublished paper) School of Economics, University of New South Wales.

Chau, F., Deesomsak, R., \& Wang, J. (2014). Political uncertainty and stock market volatility in the Middle East and North African (MENA) countries. Journal of International Financial Markets, Institutions and Money, 28, 1-19.

Civilize, S., Wongchoti, U., \& Young, M. (2015). Political connection and stock returns: A longitudinal study. Financial Review, 50(1), 89-119.

Clayton, M. C., Hartzell, J. C., \& Rosenberg, J. (2005). The Impact of CEO Turnover on Equity Volatility. The Journal of Business, 78(5), 1779-1808.

Cornell, B. (1978). Using the options pricing model to measure the uncertainty producing effect of major announcements. Financial Management, 7, 54-59.

Donders, M. W., \& Vorst, T. C. (1996). The impact of firm specific news on implied volatilities. Journal of Banking \& Finance, 20(9), 1447-1461.

Dubofsky D. (1991). Volatility increases subsequent to NYSE and AMEX stock splits. Journal of Finance, 46, 421-31.

Ederington, L. H., \& Lee, J. H. (1993). How markets process information: News releases and volatility. The Journal of Finance, 48(4), 1161-1191. 
Engle, R. F., \& Ng, V. K. (1993). Measuring and testing the impact of news on volatility. The Journal of Finance, 48(5), 1749-1778.

Fails, M. D. (2014). Leader turnover, volatility, and political risk. Politics \& Policy, 42(3), 369399.

Freeman, J. R., Hays, J. C., \& Stix, H. (2000). Democracy and markets: The case of exchange rates. American Journal of Political Science, 44(3), 449-468.

French, K. R., Leftwich, R. H., \& Uhrig, W. (1989). The effect of scheduled announcements on futures markets. (Working Paper Series No. 273). Center for Research in Security Prices, University of Chicago.

Goldman, E., Rocholl, J., \& So, J., (2009). Do politically connected boards affect firm value? Review of Financial Studies, 22(6), 2331-2360.

Gomez, E.T., \& Jomo K. S. (1997). Malaysia's Political Economy: Politics, Patronage and Profits. Cambridge University Press, Cambridge.

Goodell, J. W., \& Vahamaa, S. (2013). US presidential elections and implied volatility: The role of political uncertainty. Journal of Banking \& Finance, 37(3), 1108-1117.

Granberg, D., \& Holemberg, S. (1991). Election campaign volatility in Sweden and the United States. Electoral Studies, 10(3), 208-230.

Harvey, C. R., \& Huang, R. D. (1991). Volatility in the foreign currency futures market. Review of Financial Studies, 4(3), 543-569.

Hermes, N., \& Lensink, R. (2001). Capital flight and the uncertainty of government policies. Economics letters, 71(3), 377-381.

Hussain, S. M. (2011). Simultaneous monetary policy announcements and international stock markets response: an intraday analysis. Journal of Banking \& Finance, 35(3), 752-764.

Idris, A. N. (2018). FBM KLCI down ahead of Budget 2019. The Edge Markets. Retrieved September 22, 2020, from https://www.theedgemarkets.com/article/fbm-klci-down-aheadbudget-2019

Kalay, A., \& Loewenstein, U. (1986). The informational content of the timing of dividend announcements. Journal of Financial Economics, 16(3), 373-388.

Lean, H. H., \& Yeap, G. P. (2016). Asymmetric 13 effect of political elections on stock returns and volatility in Malaysia. In Q. Munir \& S. C. Kok (Eds.), Information Efficiency and Anomalies in Asian Equity Markets: Theories and Evidence (pp. 228-247). NY: Routledge.

Leblang, D., \& Bernhard, W. (2000). The politics of speculative attacks in industrial democracies. International Organization, 54(2), 291-324.

Leblang, D., \& Mukherjee, B. (2004). Presidential elections and the stock market: Comparing Markov-switching and fractionally integrated GARCH models of volatility. Political Analysis, 12(3), 296-322.

Liew, V. K. S., \& Rowland, R. (2016). The effect of Malaysia general election on stock market returns. SpringerPlus, 5(1), 1975. https://doi.org/10.1186/s40064-016-3648-5

Lin, C. T., \& Wang, Y. H. (2007). The impact of party alternative on the stock market: The case of Japan. Applied Economics, 39(1), 79-85.

Lim, J. (2019). KLCI flat, builders rise ahead of Budget 2020. The Edge Markets. Retrieved September 22, 2020, from https://www.theedgemarkets.com/article/klci-flat-builders-riseahead-budget-2020

Mayhew, S. (1995). Implied volatility. Financial Analysts Journal, 51(4), 8-20. https://doi.org/10.2469/faj.v51.n4.1916

Mei, J., \& Guo, L. (2004). Political uncertainty, financial crisis and market volatility. European Financial Management, 10(4), 639-657. 
Neuhierl, A., Scherbina, A., \& Schlusche, B. (2013). Market Reaction to Corporate Press Releases. Journal of Financial and Quantitative Analysis, 48(4), 1207-1240.

Oliveira, A. S. D. (2014). The effect of government budget on Portuguese stock market (Unpublished Doctoral dissertation). Universidade Catolica Portuguesa.

Opare, A. (2012). Effects of General Elections on the Return and Volatility of Stocks: The Evidence from Europe. SSRN. https://doi.org/10.2139/ssrn.2224033

Pantzalis, C., Stangeland, D. A., \& Turtle, H. J. (2000). Political elections and the resolution of uncertainty: The international evidence. Journal of Banking \& Finance, 24(10), 1575-1604.

Pastor, L., \& Veronesi, P. (2013). Political uncertainty and risk premia. Journal of Financial Economics, 110(3), 520-545.

Santa-Clara, P., \& Valkanov, R. (2003). The presidential puzzle: Political cycles and the stock market. The Journal of Finance, 58(5), 1841-1872.

Suleman, M. T. (2014). Political Risk and Volatility Spillover of Stock Returns: India and Asian Markets. SSRN. https://papers.ssrn.com/sol3/papers.cfm?abstract id=2485157

Vahamaa, S., \& Aijo, J. (2011). The Fed's policy decisions and implied volatility. Journal of Futures Markets, 31(10), 995-1010.

Wang, Y. H., Lee, M. Y., \& Lin, C. Y. (2008). General election, political change and market efficiency: Long-and short-term perspective in developed stock market. Journal of Money, Investment and Banking, 3, 58-67.

Winifred, A., \& Perez, J. (2018). Malaysia shares buck gains in Asia ahead of 2019 budget. Nikkei Markets. https://asia.nikkei.com/Business/Markets/Nikkei-Markets/Malaysia-shares-buckgains-in-Asia-ahead-of-2019-budget

Wong, W. Y., \& Hooy, C. W. (2018). Do types of political connection affect firm performance differently? Pacific-Basin Finance Journal, 51, 297-317.

Wong, W. Y. (2016). The performance of politically connected firms in long-run and short-run: Evidence from Malaysia [Unpublished Master's thesis]. Universiti Sains Malaysia. 


\section{APPENDIX}

\section{A. Cumulative abnormal volatility}

Table A-1: The table shows the cumulative abnormal volatility for the event window $(-5,+5)$ during the four events.

\begin{tabular}{|c|c|c|c|c|c|c|}
\hline & PCON & NON-PCON & PCON_GLC & PCON_BOARD & PCON_BUS & PCON_FAM \\
\hline \multicolumn{7}{|c|}{ Panel A: General election } \\
\hline$d-5$ & -4.69857 & -2.48475 & -3.7863 & -5.848 & -1.16755 & -7.99244 \\
\hline$d-4$ & -6.34761 & 2.897162 & -4.45566 & -7.22185 & -2.74968 & -10.9633 \\
\hline$d-3$ & -3.07926 & 4.662856 & 3.133854 & -2.33942 & -2.69245 & -10.419 \\
\hline $\mathrm{d}-2$ & -3.30043 & -11.5805 & -0.16123 & 2.424135 & -7.3844 & -8.08021 \\
\hline d-1 & 1.333026 & -3.40493 & 7.332888 & -2.17679 & -8.8102 & 8.986202 \\
\hline 0 & 58.82522 & 54.11442 & 60.64469 & 31.45358 & 43.3425 & 99.86012 \\
\hline$d+1$ & 2.821124 & -1.46879 & 5.492261 & 7.184023 & 12.55942 & -13.9512 \\
\hline$d+2$ & -20.3703 & -3.11481 & -4.92254 & -6.71282 & -58.1266 & -11.7192 \\
\hline$d+3$ & -8.87101 & -12.0312 & -3.30247 & -1.72294 & -28.8815 & -1.57708 \\
\hline$d+4$ & -2.66736 & -7.83054 & 1.020997 & -2.429 & -12.5585 & 3.297075 \\
\hline$d+5$ & -0.80394 & 13.85711 & 1.996605 & 6.015361 & -6.7375 & -4.49022 \\
\hline \multicolumn{7}{|c|}{ Panel B: Leadership change } \\
\hline$d-5$ & -5.45238 & -11.0957 & -3.4098 & -9.70336 & -5.98911 & -2.70726 \\
\hline$d-4$ & 1.698602 & -3.82391 & -0.41634 & -0.95288 & 10.74163 & -2.57799 \\
\hline$d-3$ & -2.93939 & -3.12683 & -2.64982 & -7.56678 & 2.415995 & -3.95696 \\
\hline$d-2$ & -2.49616 & -8.52406 & -1.76944 & -0.25588 & -4.67782 & -3.28149 \\
\hline d-1 & 20.16717 & 0.301548 & 7.123415 & 59.74745 & 2.713361 & 11.08446 \\
\hline 0 & 9.266216 & -1.9281 & -2.91152 & 47.18131 & -3.23828 & -3.96664 \\
\hline$d+1$ & -3.75289 & 7.54247 & -2.38226 & -5.21838 & -3.8513 & -3.55961 \\
\hline$d+2$ & -1.08062 & 3.769755 & -3.26971 & -5.16382 & 2.820237 & 1.290812 \\
\hline$d+3$ & -5.37366 & 8.974147 & -4.53082 & -12.3203 & -2.69088 & -1.95261 \\
\hline$d+4$ & -0.24389 & -2.83497 & -3.69714 & 2.987978 & -3.66915 & 3.402766 \\
\hline$d+5$ & 1.043258 & -2.90644 & 11.23184 & -5.81996 & -2.89716 & 1.65832 \\
\hline \multicolumn{7}{|c|}{ Panel C: Budget announcement } \\
\hline$d-5$ & -2.83443 & -1.81668 & -1.44198 & -2.583 & -4.97875 & -2.334 \\
\hline d-4 & 0.267261 & 2.585741 & -0.41917 & 1.983234 & 7.336549 & -7.83157 \\
\hline$d-3$ & -0.39602 & -2.26279 & -1.61321 & -1.3411 & -2.47049 & 3.840696 \\
\hline d-2 & -2.31223 & -1.3377 & -0.54287 & 0.315848 & -4.01134 & -5.01055 \\
\hline d-1 & -1.64892 & -3.9066 & -0.98707 & -3.17591 & -2.52735 & 0.094642 \\
\hline 0 & -1.33959 & -0.86032 & -1.24697 & -1.72801 & 2.980156 & -5.36354 \\
\hline$d+1$ & -1.55947 & -2.7685 & -2.38058 & -1.62264 & -2.8113 & 0.57664 \\
\hline$d+2$ & 2.156018 & -3.07447 & 0.294529 & -1.53729 & 13.54352 & -3.67669 \\
\hline$d+3$ & -1.84082 & -0.11934 & 0.904283 & -0.56597 & -6.74579 & -0.95582 \\
\hline$d+4$ & -3.84195 & -0.64518 & -1.33831 & -1.57609 & -7.87407 & -4.57932 \\
\hline$d+5$ & -1.95952 & 1.491042 & 1.209014 & -2.49292 & -6.51508 & -0.0391 \\
\hline \multicolumn{7}{|c|}{ Panel D: Policy announcement } \\
\hline$d-5$ & 3.599149 & 1.32811 & 0.69989 & 1.875312 & 9.344833 & 2.476561 \\
\hline $\mathrm{d}-4$ & -1.52455 & -12.7319 & -3.1863 & -0.8598 & 1.829095 & -3.88121 \\
\hline d-3 & -2.36393 & -4.07848 & 1.794041 & 1.389595 & -7.74728 & -4.89208 \\
\hline $\mathrm{d}-2$ & -2.45289 & -0.07414 & 1.164639 & -1.636 & -6.60462 & -2.73557 \\
\hline d-1 & 0.076954 & -5.1132 & -2.35925 & -1.55777 & 1.381712 & 2.843131 \\
\hline 0 & -0.72087 & -1.77692 & 2.391759 & -0.26143 & -1.68654 & -3.32729 \\
\hline$d+1$ & 1.849326 & -2.77746 & -1.97423 & 0.52977 & 3.79564 & 5.046123 \\
\hline$d+2$ & -0.50388 & 2.10195 & 3.035649 & -1.41105 & -2.75593 & -0.88418 \\
\hline$d+3$ & -3.28699 & -3.58751 & -4.03355 & 0.564534 & -6.29205 & -3.3869 \\
\hline$d+4$ & -2.6139 & 1.694276 & -0.06911 & 0.947207 & -7.15731 & -4.17638 \\
\hline$d+5$ & 1.33504 & -7.24024 & 3.710285 & 2.045171 & 0.090728 & -0.50603 \\
\hline
\end{tabular}

